\title{
NATURAL HISTORY NOTES ON FROGS FROM \\ MANAUS, AMAZONAS
}

Claude Gascon ${ }^{2}$

\begin{abstract}
Natural history accounts are presented for six species of anuran amphibians from the Manaus region. Amazonas. Varied information concerning advertisement call, clutch size, hatching success, and reproductive behavior for two species of dendrobatids and four species of hylids. The information was gathered over several years of field work and hopefully will serve to better understand the ecology of these species.

KEY WORDS. Amphibian fauna, reproduction, behavior, Amazon, Brazil
\end{abstract}

Although the amphibian fauna is well-known for many Neotropical sites (see papers in GENTRY 1990), there is still a lack of basic natural history and reproductive ecology information for most species. The amphibian fauna of the Biological Dynamics of Forest Fragments Project site has been surveyed extensively (ZIMMERMAN \& RODRIGUES 1990; GASCON 1991a), but nonetheless we are still fairly ignorant concerning many aspects of the life history of these species (see JUNCA et al. in press, for an example of a novel reproductive strategy). In this paper, I describe natural history information for several species of amphibians that occur in the Manaus (Amazonas) region. The information was gathered over several years of field work and hopefully will serve to better understand the ecology of these species.

\section{Natural history accounts}

\section{DENDROBATIDAE}

\section{Epipedobates femoralis Boulenger, 1884}

This frog corresponds in all respects to DuELLMAN's (1978) description except for the call. The call of this frog in Manaus consists of a cluster of four notes repeated at various intervals, whereas in Santa Cecilia, Ecuador, only two notes compose the call. I caught several E. femoralis carrying tadpoles on their backs. On 24 February 1988, I caught one male (SVL 3.5cm) carrying 24 tadpoles on its back. The male was less than 1 meter away from a temporary pond when it

1) Projeto Dinâmica Biológica de Fragmentos Florestais.

2) Departamento de Ecologia, Instituto Nacional de Pesquisas da Amazonia, Caixa Postal 478. 69011-970 Manaus, Amazonas, Brazil. 
was captured. On 12 April 1988, I found another male (SVL 3.2cm) with 17 tadpoles on its back. The frog was beside a plastic basin that had previously been sunk in the ground for another experiment (GASCON 1993). This basin was located only a couple of meters from natural temporary ponds. On 27 April 1988, one adult (SVL $3.4 \mathrm{~cm}$ ) was seen entering the water of a temporary pond with one tadpole on its back. It had probably unloaded the rest of the clutch in the preceding moments. On 1 May 1988, I observed another adult close to a temporary pond with more than 15 tadpoles on its back. It managed to avoid being caught. Finally, on 10 November 1988, an adult (SVL $3.3 \mathrm{~cm}$ ) was caught with 16 tadpoles on its back. Based on this small sample size, the mean clutch size of this species in the Manaus area is 19 tadpoles. This value is slightly lower than the mean clutch size of 22.4 reported by DUELLMAN (1978). Six juveniles were caught around breeding sites. Mean SVL was $1.20 \mathrm{~cm}$ (S.D. 0.27).

\section{Colostethus marchesianus Melin, 1941}

On 29 March 1988, I captured one male (SVL 1.70cm) carrying 8 tadpoles on its back. The male was found close to a small stream in a valley of terra firme forest. On 1 May 1988, I captured one male with 9 tadpoles on its back. In upland forest, I also encountered one nest of $C$. marchesianus which contained 13 eggs of which 3 were dead. The remaining 10 were developing normally into tadpoles. Based on this small sample size, mean clutch size for this species is 10 eggs. This value is very similar to another estimate in the same area (Junca et al. in press), but slightly lower that the value of 13.4 reported by DUELLMAN (1978) for frogs of this species at Santa Cecilia, Ecuador. This probably suggests that this species only carries tadpoles from one clutch at a time even though the male may guard more than one clutch in the nest (JUNCA et al. in press).

\section{HYLIDAE}

\section{Phyllomedusa tomopterna Cope, 1868}

As for all phyllomedusines, this species builds a nest above temporary ponds composed of two or three leaves of seedlings folded over to protect the eggs. A protective layer of empty egg capsules is further deposited by the female at the suture point of the leaves to prevent desiccation of the fertilized eggs. Twenty-one nests of this species were followed for hatching success from December 1987 to March 1989. Mean clutch size is 65 eggs (S.D. = 14.7, range 38-97) which is very similar to the value of 71 found at Santa Cecilia, Ecuador (DuELlman 1978). Of these 21 nests, 5 were brought back to camp to hatch in the laboratory for experiments. Hatching success overall was high ( $86 \%)$, but even higher if I exclude those nests that were taken from their natural site and transported back to camp ( $97 \%$ for the 16 nests left in situ). This higher mortality for manipulated nests is probably due to the drying of the leaves that compose the nest due to removal from their natural site. This low mortality under natural conditions suggests that very 
little mortality occurs in the egg stage compared to aquatic breeders (e.g. GASCON 1991b). Mortality in the nest was mainly due to desiccation (when the nest was not well sealed with empty egg capsules) or due to predation by a small diptera that lays eggs in the egg jelly and the larvae feed on the eggs in a similar manner as described for Leptodactylus knudseni Heyer, 1972, (GASCON 1991b). No case of predation by vertebrates, mainly snakes, was recorded.

\section{Phyllomedusa tarsius Cope, 1868 and Phyllomedusa bicolor Boddaert, 1772}

Nests of these two species can easily be distinguished from those of $P$. tomopterna by the larger size and the white eggs (yellow in P. tomopterna). Five nests of $P$. tarsius were encountered with a mean clutch size of 272 eggs $(\mathrm{s} . \mathrm{d} .=83.0$, range 200-400). Only one estimate of hatching success was obtained: $95 \%$ of eggs in one nest hatched. Two nests of $P$. bicolor were found and clutch size is much large than for the 2 other Phyllomedusa spp. (1215 eggs). As for $P$. tomopterna, most mortality occurs in the tadpole stage. I observed on many occasions high mortality at egg hatching by adults of Pipa arrabali Izecksohn, 1976. This aquatic frog is present in many of the breeding sites and are very voracious predators of hatchlings of Phyllomedusa spp. in most cases picking off the hatchlings as they fall from the nest before they hit the water.

\section{Osteocephalus taurinus Steindachner, 1862}

This is a very common frog in the Instituto Nacional de Pesquisas da Amazônia - Smithsonian Institution reserves. It lays eggs as a surface film and mean clutch size is 2341 eggs ( $\mathrm{s} . \mathrm{d} .=582, \mathrm{n}=4$, range 1794-3154). Six amplectant pairs were observed from 26 October 1988 to 5 April 1989. Mean male size was $8.4 \mathrm{~cm}$ (s.d. $=0.47$, range $7.8-9.1$ ), while mean female size was $10.0 \mathrm{~cm}$ (s.d. =0.31, range 9.7-10.5). No size-assortative mating was noted in this species (Pearson correlation $=-0.055$ ) indicating that small males can mate with either small or large females.

ACKNOWLEDGEMENTS. This study was supported by World Wildlife Fund, Instituto Nacional de Pesquisas da Amazônia, Smithsonian Institution, and Sigma Xi, The Scientific Research Society. Additional support was provided from a Graduate Fellowship from FCAR (Quebec). I wish to thank O. Pereira and L. dos Reis for their great help in all aspects of field work. Support during the preparation of this manuscript was provided by a RHAE Fellowhip from CNPq (Brazil). Publication \# 129 of the Biological Dynamics of Forest Fragments Project.

\section{BIBLIOGRAPHIC REFERENCES}

Duellman, W.E. 1978. The biology of an equatorial herpetofauna in Amazonian Ecuador. Univ. Kansas Misc. Publ. 65: 1-352.

Gascon, C. 1991a. Population and community level analyses of species 
occurrences of central Amazonian forest tadpoles. Ecology 72: 1731-1746. 1991b. Breeding of Leptodactylus knudseni: responses to rainfall variation. Copeia 1991: 248-252.

- 1993. Breeding-habitat use by five Amazonian frogs at forest edge. Biodiversity and Conservation 2: 438-444.

Gentry. A.H. 1990. Four Neotropical Forests. Yale University Press, New Haven, Connecticut, 627p.

JunCA, F.A.; R. Altig \& C. GasCon. 1994. Breeding biology of Colostethus stepheni, a dendrobatid frog with a non-transported nidicolous tadpole. Copeia 1994: 747-750.

ZIMMERMAN, B.L. \& M.T. Rodrigues. 1990. Frogs, snakes, and lizards of the INPA-WWF reserves near Manaus, Brazil, p. 426-454. In: A.H. GENTRY (ed.). Four Neotropical Rainforests. New Haven, Connecticut, Yale University Press, 627p..

Recebido em 30.XII. 1994; aceito em 13.I.1995. 